\title{
Pengaruh Umur Perusahaan Dan Sales Growth Terhadap Tax Avoidance
}

\author{
Lindawati Ziliwu', Ajimat ${ }^{2 *}$, \\ ${ }^{1,2}$ Fakultas Ekonomi dan Bisnis Universitas Pamulang \\ lindawatiziliwu36@gmail.com ${ }^{1}$; math.unpam@gmail.com ${ }^{2 *}$ \\ Received 06 Juli 2021| Revised 20 Juli 2021 | Accepted 30 Juli 2021 \\ *Korespondensi Penulis
}

\begin{abstract}
Abstrak
Penelitian ini bertujuan untuk mengetahui pengaruh Umur Perusahaan dan Sales Growth tehadap Tax Avoidance. Metode penelitian yang digunakan yaitu metode kuantitatif. Sampel dalam penelitian dari perusahaan sektor barang konsumsi periode 2015-2019 sebanyak 20 Perusahaan selama 5 Tahun. Teknik analisis yang digunakan adalah statistika deskriptif, asumsi klasik, koefisien deterinasi dan uji hipotesis. Hasil penelitian menunjukan parsial Umur Perusahaan berpengaruh terhadap Tax Avoidance, Sales Growth berpengaruh terhadap Tax Avoidance dan secara simultan Umur Perusahaan dan Sales Growth berpengaruh terhadap Tax Avoidance sebesar 3,26\% dan sisanya sebesar 96,74 di pengaruhi oleh variabel lain.
\end{abstract}

Kata Kunci: Umur Perusahaan; Sales Growth; Tax Avoidance

\begin{abstract}
This study aims to determine the influence of Company Age and Sales Growth on Tax Avoidance. The research method used is the quantitative method. Sample in the study of companies in the consumer goods sector for the period 2015-2019 as many as 20 companies for 5 years. The analysis techniques used are descriptive statistics, classical assumptions, deterrence coefficients and hypothesis testing. The results showed that partial Company Age affects Tax Avoidance, Sales Growth affects Tax Avoidance and simultaneously Company Age and Sales Growth affects Tax Avoidance by 3.26\% and the rest as much as $96.74 \%$ is influenced by other variables.
\end{abstract}

Keywords: Company Age; Sales Growth affects; Tax Avoidance

\section{PENDAHULUAN}

Indonesia merupakan salah satu negara dalam fase proses perkembangan pembangunan nasional yang berlangsung secara bertahap, menuju perubahan dalam meningkatkan bangsa yang lebih baik. Tetapi, ketika dalam mencapai perubahan tersebut Indonesia dihadapkan pada berbagai permasalahan, problematika dan kasus, yang salah satunya dalam permasalahan perpajakan. Dalam peraturan rundangundang Nomor 28 ditahun 2007 pasal 1 (1), pajak diartikan sebagai partisipasi wajib terhadap negeri yang terutang oleh WP orang pribadi ataupun Badan dimana bersifat memaksa yang didasarkan pada perundang - undangan, dengan tidak mendapatkan bayaran secara terang-terangan serta digunakan bagi kebutuhan negara sebesar-besarnya guna kemakmuran rakyat.

Pajak merupakan akar mendasar dari pemasukan suatu negara, untuk itu diperlukan kesadaran dari wajib pajak akan kewajiban pajaknya, karena pajak yang terkumpul digunakan untuk pembangunan infrastruktur,pembangunan pendidikan, kesehatan, serta pembangunan fasilitas publik. Oleh sebab itu, 
sudah sepatutnya masyarakat wajib pajak memahami pentingnya pajak bagi negara dan sadar untuk membayar pajak. Namun,dalam pelaksanaannya ada sebagian wajib pajak yang tidak sependapat. Menurut Susanti (2018) dalam pelaksanaannya WP dan pemerintah memiliki relevansi yang berbeda terkait dengan pelunasan pajak, bagi wajib pajak, pajak merupakan salah satu kewajiban yang akan mengurangi laba atau penghasilan yang diperoleh, sedangkan pemerintah berkeinginan penerimaan pajak yang kian meningkat untuk pendapatan negara.

Pertentangan kepentingan tersebut yang menyebabkan wajib pajak condong melakukan pengelakan pajak untuk menurunkan pembayaran pajaknya. Dari indisiplinan yang dilakukan wajib pajak tersebut, berdampak pada upaya wajib pajak dalam melancarkan tax avaoidance.Tax avoidance adalah upaya penghindaran pajak yang dilakukan secara legal dan aman bagi wajib pajak karena tidak bertentangan dengan ketentuan perpajakan, dimana metode dan teknik yang digunakan cenderung memanfaatkan kelemahan-kelemahan (grey area) yang terdapat dalam Undang-Undang dan peraturan perpajakan itu sendiri, untuk memperkecil jumlah pajak yang terutang (Febby, 2019).

Sebagai contoh yaitu pada tahun 2018, Kasus Astra Internasional Tbk (ASII) yang salah satu anak perusahaannya yaitu PT Toyota Motor Manufacturing Indonesia (TMMIN) mengumumkan kinerja ekspor mobil utuh atau Completely Built Up (CBU) mereka pada tahun lalu. Jumlahnya mencatat rekor yakni lebih dari 118 ribu unit. Jumlah ini setara dengan 70 persen total ekspor kendaraan dari Indonesia tahun lalu. Jika ditambah dengan produk mobil terurai atau Complete Knock Down (CKD) dan komponen kendaraan, maka nilai ekspor pabrik mobil yang 95 persen sahamnya dikuasai Toyota Motor Corporation (TMC) Jepang tersebut mencapai US\$ 1,7 miliar atau sekitar Rp 17 triliun. Namun Direktorat Jenderal Pajak Kementerian Keuangan menemukan bukti bahwa Toyota Motor Manufacturing memanfaatkan transaksi antar-perusahaan terafiliasi yang ada di dalam dan luar negeri untuk menghindari pembayaran pajak perusahaannya. Modusnya sederhana yaitu memindahkan beban keuntungan berlebih dari satu negara ke negara lain yang menerapkan tarif pajak lebih murah (tax heaven). Pemindahan beban dilakukan dengan cara memanipulasi harga secara tidak wajar. Telah terungkap bahwa seribu mobil buatan Toyota Motor Manufacturing Indonesia harus dijual dulu ke kantor Toyota Asia Pasifik di Singapura, sebelum berangkat dan dijual ke Filipina dan Thailand. Hal ini dilakukan untuk menghindari membayar pajak yang tinggi di Indonesia. Dengan kata lain, Toyota di Indonesia hanya bertindak "atas nama" Toyota Motor Asia Pacific Pte., Ltd - yaitu nama unit bisnis Toyota yang berkantor di Singapura (http://investigasi.tempo.co). (Afiati, 2019)

Dalam teori keagenan, praktik tax avoidance dapat dilakukan secara maksimal oleh pihak manajemen karena dilandasi pengetahuan atas riil information yang lebih memadai dibandingkan dengan pemilik perusahaan. Praktik tax avoidance di suatu perusahaan di dorong oleh berbagai macam faktor, salah satunya adalah faktor umur perusahaan dan sales growth.

Umur perusahaan diduga menjadi salah satu faktor dari perusahaan untuk melakukan penghindaran pajak. Perusahaan memiliki siklus hidup yang semakin lama akan semakin mengalami penurunan, seiring berjalannya waktu perusahaan akan semakin tidak efisien. Perusahaan yang sudah menua dan sudah tidak efisien tentunya akan berupaya agar perusahaannya kembali menjadi efisien. Perusahaan akan mengurangi pengeluaran biaya agar bisa efisien. Salah satu biaya yang dikurangi yaitu biaya pajak. Perusahaan akan berupaya memperkecil biaya pajaknya agar performa perusahaan terlihat baik. Dilain sisi perusahaan yang sudah lama berdiri tentunya memiliki pengalaman di bidang akuntansi yang lebih baik dibandingkan perusahaan yang masih baru. Perusahaan yang sudah lama berdiri sudah mengetahui celah - celah hukum mana saja yang dapat digunakan untuk mengurangi beban pajak mereka. Sehingga semakin tua umur perusahaan maka, ada kecenderungan lebih besar dari perusahaan untuk melakukan tindakan tax avoidance.

Sales Growth juga di indikasikan berpengaruh terhadap tax avoidance. Sales Growth merupakan rasio yang menggambarkan kemampuan perusahaan dalam mempertahankan posisi ekonominya ditengah pertumbuhan dan sektor usahanya, Muhammad (2020). Dengan adanya peningkatan penjualan 
maka aset pun juga harus bertambah yang dimana perusahaan rela untuk melakukan penghindaran pajak karena disisi lain laba yang meningkat akibat adanya peningkatan penjualan akan menyebabkan beban pajak yang ditanggung perusahaan juga ikut meningkat (Febby, 2019).

Hubungan sales growth terhadap tax avoidance terdapat dalam penelitian Susanti (2018) yang menunjukkan hasil bahwa variabel Sales Growth memiliki pengaruh positif terhadap Tax Avoidance dikarenakan perusahaan yang sedang mengalami grafik pertumbuhan penjualan yang meningkat maka akan menyebabkan perolehan laba yang semakin besar sehingga perusahaan akan berusaha untuk menghindari pembayaran pajak

Penelitian mengenai tax avoidance di Indonesia masih belum banyak dijumpai karena keterbatasan data mengenai pajak perusahaan. Pengukuran tax avoidance sering kali masih menggunakan beberapa pendekatan tidak langsung. Berdasarkan latar belakang di atas maka tujuan dari penelitian ini adalah untuk mengetahui faktor- faktor yang mempengaruhi terhadap penerapan tax avoidance. Penelitian ini untuk menguji lebih lanjut pengaruh umur perusahaan dan sales growth terhadap tax avoidance.

\section{Teori Keagenan (Agency Theory)}

Menurut Jensen \& Meckling (1976) mendefinisikan filosofi Agency Theory sebagai kontrak antara satu atau beberapa orang principal yang mendelegasikan wewenang kepada orang lain (agent) untuk mengambil keputusan dalam menjalankan perusahaan. fundamen utama dalam teori ini adalah dekrit adanya ikatan kinerja antara pihak yang memberi kuasa (principal) yaitu pemilik (pemegang saham), kreditor, dan investor melalui pihak yang menerima kuasa (agent) yaitu manajemen perusahaan, melalui sistem kontrak kolaborasi. Ketika mengambil keputusan, terkadang manajemen mengabaikan kepentingan pemilik dengan alasan agar perusahaan mampu mendapatkan keuntungan yang sebesarbesarnya, sehingga menyebabkan manajemen mampu mengambil tindakan transfer pricing untuk menghindari adanya pajak (tax avoidance). Dengan tarif pajak yang ditetapkan lebih rendah dari pada perusahaan induk, tanpa adanya pelanggaran terhadap ketentuan yang berlaku.

\section{Tax Avoidance}

Tax Avoidance adalah usaha untuk menghindari pajak yang dilakukan dengan cara yang legal atau tidak melanggar peraturan perundangan karena bagi perusahaan pajak dianggap sebagai beban yang akan mengurangi keuntungan perusahaan, Harry (2018). Karena masih berada dalam bingkai peraturan perpajakan yang berlaku. Perusahaan akan berusaha mengelola beban pajaknya seminimum mungkin supaya memperoleh laba yang maksimal. Biasanya perusahaan melakukan strategi-strategi atau caracara yang legal sesuai dengan aturan undang-undang yang berlaku, namun dilakukan dengan memanfaatkan hal-hal yang sifatnya ambigu dalam undang-undang sehingga dalam hal ini wajib pajak memanfaatkan celah-celah yang ditimbulkan oleh adanya ambiguitas dalam undang-undang perpajakan. Meski penghindaran pajak bersifat legal, dari pihak pemerintah tetap tidak menginginkan hal tersebut (Suripto, 2020). Lebih lanjut, OECD mendeskripsikan bahwa tax avoidance adalah usaha wajib pajak untuk mengurangi pajak terutang, meskipun upaya ini bisa jadi tidak melanggar hukum (the letter of the law), namun sebenarnya bertentangan dengan tujuan dibuatnya peraturan peraturan perundangundangan perpajakan (the spirit of the law) (Cahya,2019).

\section{Umur Perusahaan}

Umur perusahaan menunjukkan seberapa lama perusahaan mampu bersaing dalam memanfaatkan peluang bisnis dalam suatu perekonomian. Dengan mengetahui umur perusahaan, maka akan diketahui juga sejauh mana sejarah perusahaan tersebut dapat bertahan. Semakin panjang umur perusahaan akan memberikan pengungkapan informasi keuangan lebih luas dengan alasan perusahaan memiliki pengalaman lebih dalam pengungkapan laporan tahunan. Umur perusahaan mencerminkan seberapa 
lama perusahaan berdiri dan dapat bertahan di BEI. Umur perusahaan menunjukkan seberapa lama perusahaan mampu bersaing di dalam dunia usaha.Umur perusahaan yang digunakan sebagai acuan adalah umur perusahaan dari tanggal perusahaan terdaftar di BEI. Hal ini dikarenakan pada saat perusahaan sudah terdaftar di BEI maka perusahaan sudah mempunyai tanggung jawab untuk mempublikasikan laporan keuangannya kepada masyarakat dan pemakai laporan keuangan agar informasi yang ada di dalamnya dapat segera digunakan oleh pihak-pihak yang membutuhkan dalam mengambil keputusan investasi.

\section{Sales Growth}

Pertumbuhan penjualan dapat diartikan dengan meningkatnya jumlah penjualan dari tahun sebelumnya yang diakibatkan karena pembelian barang oleh konsumen. Perusahaan dapat mengoptimalkan dengan baik sumber daya yang ada dengan melihat penjualan dari tahun sebelumnya. Sales growth mempunyai peran penting di dalam manajemen modal kerja sebuah perusahaan (Sri,2019). Perusahaan dapat memprediksi seberapa besar profit yang akan diperoleh perusahaan dengan besarnya pertumbuhan penjualan. Dengan ingkat penjualan yang tinggi akan mempengaruhi pertumbuhan penjualan. Pertumbuhan penjualan juga merupakan indikator permintaan dan daya saing perusahaan dalam suatu industri, Peningkatan pertumbuhan penjualan cenderung akan membuat perusahaan profit yang besar, maka dari itu perusahaan akan cenderung untuk melakukan praktik tax avoidance karena profit yang besar akan menghasilkan pajak yang besar pula.

\section{Penelitian Terdahulu}

Penelitian Ida Ayu Rosa Dewinta (2016) yang berjudul "Pengaruh Ukuran Perusahaan, Umur Perusahaan, Profitabilitas, Leverage, Dan Pertumbuhan PenjualanTerhadap Tax Avoidance”, diperoleh hasil bahwa umur perusahaan berpengaruh terhadap tax avoidance.

Penelitian Shinta Meilina Purwanti (2018) yang berjudul "Pengaruh Intensitas Aset Tetap, Pertumbuhan Penjualan dan Koneksi Politik Terhadap Tax Avoidance" diperoleh hasil bahwa pertumbuhan penjualan berpengaruh terhadap tax avoidance.

\section{Kerangka Berpikir}

Menurut Sugiyono (2013: 60) " kerangka berfikir adalah model konseptual tentang bagaimana sebuah teori memiliki hubungan dengan berbagai faktor yang telah diidentifikasi sebagai masalah yang penting”. Kerangka berpikir dalam penelitian ini seperti ditunjukkan pada gambar 1

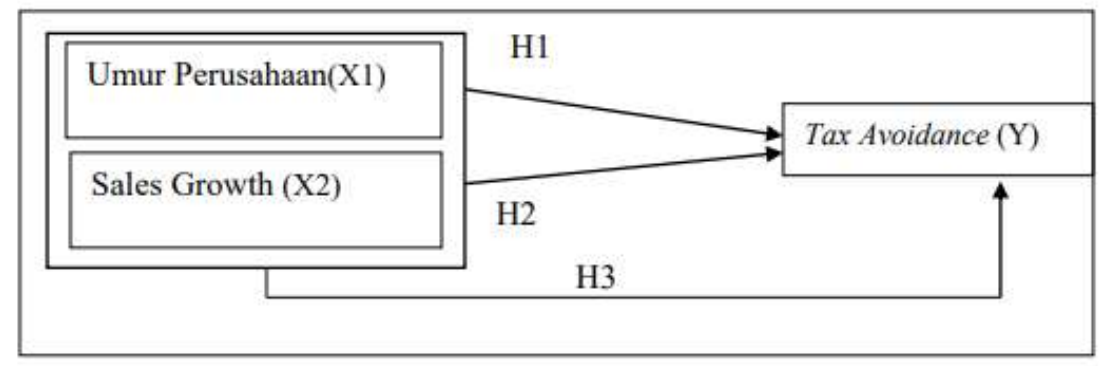

Sumber : Lidia W. (2017)

Gambar 1. Kerangka Berpikir

\section{Hipotesis Penelitian}

Hipotesis dalam penelitian ini:

Pengaruh Umur Perusahaan terhadap Tax Avoidance $\left(\mathrm{H}_{1}\right)$

Umur Perusahaan merupakan lamanya perusahaan berdiri dalam melaksanakan kegiatan operasionalnya secara berkelanjutan sampai saat ini. Perusahaan memiliki siklus hidup yang semakin 
lama akan semakin mengalami penurunan. Seiring berjalannya waktu perusahaan akan semakin tidak efisien. Perusahaan akan mengurangi pengeluaran biaya agar bisa efisien. Salah satu biaya yang dikurangi yaitu biaya pajak. Perusahaan akan berupaya memperkecil biaya pajaknya agar performa perusahaan terlihat baik sehingga perusahaan akan cenderung melakukan tax avoidance. Penelitian tentang umur perusahaan terhadap Tax Avoidance dilakukan oleh Aji (2019) dan Silvia (2017) yang menyatakan bahwa Umur Perusahaan berpengaruh terhadap Tax Avoidance.

\section{Pengaruh Sales Growth terhadap Tax Avoidance $\left(\mathrm{H}_{2}\right)$}

Sales Growth merupakan peningkatan pertumbuhan penjualan yang terjadi di suatu perusahaan dengan membandingkan antara besaran penjualan tahun ini dengan tahun sebelumnya, Pertumbuhan penjualan pada suatu perusahaan menunjukkan bahwa semakin besar volume penjualan maka laba yang akan dihasilkan pun akan meningkat. Semakin besar profit yang diterima oleh suatu perusahaan maka beban pajak yang dihasilkan akan semakin besar, karena hal tersebut cenderung membuat perusahaan melakukan tax avoidance untuk mengurangi beban pajak perusahaannya. Penelitian tentang sales growth terhadap tax avoidance dilakukan oleh Febby (2019) yang menyatakan bahwa sales growth berpengaruh terhadap tax avoidance, hal ini sejalan dengan penelitian afiati (2019) yang menyatakan bahwa sales growth berpengaruh terhadap tax avoidance.

\section{Pengaruh Umur Perusahaan dan Sales Growth terhadap Tax Avoidance $\left(\mathrm{H}_{3}\right)$}

Umur Perusahaan merupakan lamanya perusahaan berdiri dalam melaksanakan kegiatan operasionalnya secara berkelanjutan sampai saat ini. Sales Growth merupakan peningkatan pertumbuhan penjualan yang terjadi di suatu perusahaan dengan membandingkan antara besaran penjualan tahun ini dengan tahun sebelumnya. Perusahaan yang sudah lama berdiri tentunya memiliki pengalaman di bidang akuntansi yang lebih baik dibandingkan perusahaan yang masih baru. Perusahaan yang sudah lama berdiri sudah mengetahui celah - celah hukum mana saja yang dapat digunakan untuk mengurangi beban pajak mereka. Sehingga semakin tua umur perusahaan maka, ada kecenderungan lebih besar dari perusahaan untuk melakukan tindakan tax avoidance apalagi ketika perusahaan dalam keadaan mengalami pertumbuhan penjualan yang signifikan dibanding tahun lalu, maka dengan pengalaman yang dimiliki, perusahaan akan melakukan tax avoidance untuk menurunkan beban pajak yang akan dibayar. Penelitian tentang umur perusahaan dan sales growth terhadap tax avoidance dilakukan oleh Febby (2019) yang menyatakan bahwa umur perusahaan dansales growth berpengaruh terhadap tax avoidance, hal ini sejalan dengan penelitian dan Silvia (2017) yang menyatakan bahwa sales growth berpengaruh terhadap tax avoidance.

\section{METODE}

\section{Populasi dan Sampel}

Populasi dalam observasi ini adalah perusahaan sub sektor barang konsumsi yang terdokumentasi dalam Bursa Efek Indonesia dengan rentang waktu mulai dari tahun 2015 hingga 2019. Sample pada penelitian ini adalah perusahaan sektor industri barang konsumsi. Purposive sampling digunakan dengan menggunakan kriteria (1) perusahaan sektor barang konsumsi yang terdaftar terus menerus dan tidak mengalami delisting selama periode penelitian (2) Perusahaan yang mempublikasikan laporan keuangan tahunan secara lengkap data yang di butuhkan untuk pengambilan data penelitian, sehingga diperoleh sampel sebanyak 20 perusahaan.

\section{Instrumen Penelitian}

Tax Avoidance (Y) merupakan Tax Avoidance adalah usaha untuk menghindari pajak yang dilakukan dengan cara yang legal atau tidak melanggar peraturan perundangan karena bagi perusahaan 
pajak dianggap sebagai beban yang akan mengurangi keuntungan perusahaan. Pengukuran variabel tax avoidance menggunakan ETR = Beban Pajak $:$ Laba sebelum pajak .

Umur Perusahaan $\left(\mathbf{X}_{\mathbf{1}}\right)$ Umur Perusahaan merupakan lamanya perusahaan berdiri dalam melaksanakan kegiatan operasionalnya secara berkelanjutan sampai saat ini. Dalam penelitian ini umur perusahaan di ukur menggunakan Umur = Tahun IPO di Bursa - Tahun Penelitian

Sales Growth $\left(\mathbf{X}_{2}\right)$ merupakan peningkatan pertumbuhan penjualan yang terjadi di suatu perusahaan dengan membandingkan antara besaran penjualan tahun ini dengan tahun sebelumnya. Sales growth dalam penelitian ini di ukur menggunakan rumus Sales Growth $=[\mathrm{Pt}-(\mathrm{P}-\mathrm{t} 1)]:(\mathrm{P}-\mathrm{t} 1)$.

\section{HASIL DAN PEMBAHASAN}

\section{Deskripsi Umum Data Penelitian}

Tabel 1. Deskripsi Data Penelitian

\begin{tabular}{|c|c|c|}
\hline Keterangan & & Jumlah \\
\hline $\begin{array}{l}\text { Jumlah perusahaan sektor Barang } \\
\text { Konsumsiyang terdaftar di BEI tahun 2015- } \\
2019\end{array}$ & & 51 \\
\hline $\begin{array}{l}\text { Perusahaan sektor Barang Konsumsiyang tidak } \\
\text { menerbitkan Annual Report, laporan keuangan } \\
\text { serta data-datanya tidak lengkap tahun 2015- } \\
2019\end{array}$ & (31) & \\
\hline Jumlah sampel penelitian terpilih & & 20 \\
\hline Jumlah pengamatan (Tahun) & & 5 \\
\hline $\begin{array}{l}\text { Jumlah sampel total selama periode } \\
\text { penelitian }\end{array}$ & & 100 \\
\hline
\end{tabular}

Sumber: Data sekunder diolah 2021

\section{Pemilihan Model Regresi Data Panel}

Pemilihan Model regresi yang paling baik untuk di gunakan dalam penelitian ini menggunakan bantuan Software Eviews versi 11 for windows.

Uji Chow, digunakan untuk memilih antara model common effect dan fixed effect. Jika nilai probabilitas F $<\alpha$ (Taraf signifikansi 5\%) maka Fixed Effect Model yang terpilih. Jika probabilitas F > $\alpha$ (taraf signifikansi 5\%) maka Common Effect Model yang dipilih.

Tabel 2. Hasil Uji Chow

\begin{tabular}{|lrrr|}
\hline Redundant Fixed Effects Tests & & & \\
Equation: Untitled & & & \\
Test cross-section fixed effects & & & \\
\hline \hline Effects Test & Statistic & d.f. & Prob. \\
\hline \hline Cross-section F & 3.573391 & $(19,78)$ & 0.0000 \\
Cross-section Chi-square & 62.617439 & 19 & 0.0000 \\
\hline \hline
\end{tabular}

Berdasarkan hasil dari uji Chow pada Tabel diatas, diketahui nilai F probability adalah 0,0000. Karena nilai probabilitas $0,000<0,05$, maka H0 ditolak dan H1 diterima. Dengan demikian model estimasi yang digunakan adalah model fixed effect model (FEM).

Uji Hausman, Uji Hausman test dilakukan untuk menguji model terbaik antara fixed effect model dengan random effect model. Jika nilai F-probabilitas lebih kecil $(<)$ dari $\alpha$ yang di tentukan, maka 
model fixed effect diterima, dan jika sebalikya jika nilai F-probabilitas lebih besar $(>)$ dari $\alpha$, maka model random effect yang diterima, pada penelitian ini taraf signifikansi adalah 0,05

Tabel 3. Hasil uji Hausman

\begin{tabular}{|lrrr|}
\hline $\begin{array}{l}\text { Correlated Random Effects - Hausman Test } \\
\text { Equation: Untitled } \\
\text { Test cross-section random effects }\end{array}$ & & & \\
\hline \hline Test Summary & $\begin{array}{c}\text { Chi-Sq. } \\
\text { Statistic }\end{array}$ & Chi-Sq. d.f. & Prob. \\
\hline \hline Cross-section random & 3.304412 & 2 & 0.1916 \\
\hline \hline
\end{tabular}

Berdasarkan tabel diatas nilai probabilitas menunjukan angka $0,1916>\alpha 0,05$, dapat disimpulkan bahwa model yang terpilih adalah Random Effect Model (REM). Selanjutnya dilakukan uji Lagrange multiplier untuk menentukan metode yang di gunakan dalam penelitian ini.

Uji Lagrange Multiplier, Pengujian terakhir yaitu uji lagrange multiplier dengan hipotesis jika nilai probabilitas Chi-Square $<0,05$ maka hipotesis diterima dan metode yang terbaik adalah random effect dan sebaliknya apabila nilai Chi-Square $>0,05$ maka hipotesis di tolak dan metode yang terbaik di gunakan untuk pengujian adalah metode fixed effect, dibawah ini merupakan hasil uji Lagrange Multiplier.

Tabel 4. Hasil Uji Lagrange Multiplier

\begin{tabular}{|c|c|c|c|}
\hline \multicolumn{4}{|c|}{$\begin{array}{l}\text { Lagrange multiplier (LM) test for panel data } \\
\text { Date: } 06 / 03 / 21 \text { Time: } 20: 06 \\
\text { Sample: } 20152019 \\
\text { Total panel observations: } 100 \\
\text { Probability in () }\end{array}$} \\
\hline $\begin{array}{l}\text { Null (no rand. effect) } \\
\text { Alternative }\end{array}$ & $\begin{array}{l}\text { Cross-section } \\
\text { One-sided }\end{array}$ & $\begin{array}{l}\text { Period } \\
\text { One-sided }\end{array}$ & Both \\
\hline Breusch-Pagan & $\begin{array}{l}18.30920 \\
(0.0000)\end{array}$ & $\begin{array}{l}0.029486 \\
(0.8637)\end{array}$ & $\begin{array}{l}18.33868 \\
(0.0000)\end{array}$ \\
\hline
\end{tabular}

\section{Kesimpulan Model}

Berdasarkan hasil pengujian maka uji hipotesis dalam penelitian ini menggunakan random effect model dengan gambaran sebagai berikut:

Tabel 5. Kesimpulan Model

\begin{tabular}{|c|l|c|c|}
\hline No & \multicolumn{1}{|c|}{ Metode } & Pengujian & Hasil \\
\hline 1 & Uji Chow Test & Common Effect Vs Fixed Effect & Fixed Effect \\
\hline 2 & Hausman Test & Fixed Effect Vs Random Effect & Random Effect \\
\hline 3 & Lagrange Multiplier & Common Effect Vs Random Effect & Random Effect \\
\hline
\end{tabular}

\section{Analisis Statistika Deskriptif}

Variabel - variabel yang di gunakan dalam penelitian ini antara lain meliputi variabel dependen atau (Y) yaitu Tax Avoidance serta variabel independen atau (X) yaitu (Umur Perusahaan dan Sales Growth). Berikut Statistika Deskriptif:

Tabel 6. Statistika Deskriptif

\begin{tabular}{lrrr}
\hline \hline & $Y$ & $X 1$ & $X 2$ \\
\hline \hline Mean & 0.241811 & 21.30000 & 0.246728 \\
Median & 0.253000 & 24.00000 & 0.075350 \\
Maximum & 0.814600 & 38.00000 & 11.05010 \\
Minimum & -0.330000 & 1.000000 & -0.895800 \\
Std. Dev. & 0.119748 & 10.13594 & 1.447897 \\
Skewness & -1.540384 & -0.603715 & 6.806630 \\
Kurtosis & 17.89123 & 2.254940 & 48.22782
\end{tabular}




$\begin{array}{lccc}\text { Jarque-Bera } & 963.4997 & 8.387498 & 9295.320 \\ \text { Probability } & 0.000000 & 0.015090 & 0.000000 \\ \text { Sum } & 24.18110 & 2130.000 & 24.67280 \\ \text { Sum Sq. Dev. } & 1.419612 & 10171.00 & 207.5442 \\ & & & \\ \text { Observations } & 100 & 100 & 100\end{array}$

Pada tabel diatas menunjukan hasil dari statistika deskriptif dengan jumlah sampel penelitian sebanyak 100 selama periode 2015-2019. Adapun interprestasi dari statistika deskriptif sebagai berikut:

Hasil statistika deskriptif untuk variabel Tax Avoidance (Y) menunjukan nilai minimum sebesar $-0,33$. Nilai maksimum sebesar 0,814 dengan nilai rata-rata (mean) sebesar 0,241 dan penyimpangan (standard deviation) sebesar 0,119 .

Hasil statistika deskriptif untuk variabel Umur Perusahaan (X1) menunjukan nilai minimum sebesar 1,0. Nilai maksimum sebesar 38 dengan nilai rata-rata (mean) sebesar 21,3 dan penyimpangan (standard deviation) sebesar 10,135.

Hasil statistika deskriptif untuk variabel Sales Growth (X2) menunjukan nilai minimum sebesar -0,89. Nilai maksimum sebesar 11,050 dengan nilai rata-rata (mean) sebesar 0,246 dan penyimpangan (standard deviation) sebesar 1,477.

\section{Uji Asumsi Klasik}

\section{Uji Normalitas}

Dalam penelitian ini, uji normalitas terhadap residual dengan menggunakan uji Jarque-Bera (J-B) dengan tingkat signifikansi 0.05 , Jika nilai probabilitas $>0,05$, maka asumsi normalitas terpenuhi dan Jika probabilitas $<0,05$, maka asumsi normalitas tidak terpenuhi

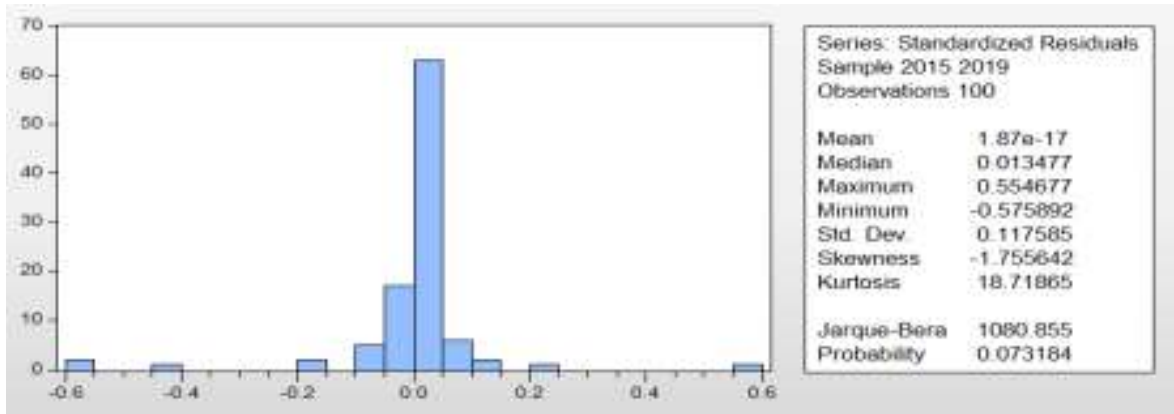

Gambar 3. Uji Normalitas

Berdasarkan gambar 3., diketahui nilai probabilitas dari statistik J-B adalah 0,073184. Karena nilai probabilitas p yakni 0,073184 lebih besar dibandingkan tingkat signifikansi 0,05. Hal ini berarti asumsi normalitas terpenuhi.

\section{Uji Multikolinearitas}

Dalam penelitian ini, gejala multikolinearitas dapat dilihat dari korelasi antar variabel. Ghozali (2013) menyatakan jika nilai X1 ke X2 terjadi peningkatan lebih dari 0,8 maka diindikasi adanya multikolinearitas. Hasil uji multikolinearitas disajikan pada tabel berikut:

Tabel 7. Hasil Uji Multikolinearitas

\begin{tabular}{crr} 
& \multicolumn{1}{c}{ X1 } & \multicolumn{1}{c}{ X2 } \\
\hline \hline X1 & 1.000000 & -0.070298 \\
X2 & -0.070298 & 1.000000
\end{tabular}

Berdasarkan tabel di atas hasil pengujian multikolinearitas, korelasi antara X1 dan X2 sebesar 0,070298. Indikasi terjadinya multikolinearitas apabila koefisien korelasi diantara masing masing 
variabel lebih besar dari 0,80 . Maka jika dilihat dari hasil penelitian diatas tidak ada korelasi antara variabel independen yang tinggi diatas 0,80 , sehingga pada penelitian ini tidak terdapat multikolinearitas antar variabel independen.

\section{Uji Heteroskedastisitas}

Model regresi yang baik adalah model yang homokedastisitas atau tidak terjadi heteroskedastisitas. Deteksi ada tidaknya heteroskedastisitas dapat dilakukan dengan uji Resabs

Tabel 8. Uji Heteroskedastisitas

\begin{tabular}{crrr|c|}
\hline \hline Variable & Coefficient & Std. Error & t-Statistic & Prob. \\
\hline \hline C & 0.067665 & 0.036177 & 1.870374 & 0.0644 \\
X1 & -0.000895 & 0.001527 & -0.586124 & 0.5592 \\
X2 & 0.007637 & 0.006661 & 1.146537 & 0.2544 \\
\hline \hline
\end{tabular}

Berdasarkan hasil uji Glejser pada Tabel diatas, seluruh nilai Prob dari variabel yang di teliti dalam penelitian ini> 0.05 , maka disimpulkan tidak terjadi heteroskedastisitas.

\section{Uji Autokorelasi}

Uji autokorelasi merupakan bagian dari uji asumsi klasik, uji autokorelasi menunjukan hasil yang dapat mendeteksi ada atau tidaknya autokorelasi dalam analisis regresi. Penulis menggunakan uji autokorelasi Durbin-Watson dalam pengujian data dengan maksud untuk menguji apakah dalam model regresi linear terdapat korelasi antar kesalahan pengganggu pada periode $\mathrm{T}$ dengan $\mathrm{T}-1$ / sebelumnya. Teori dasar pengambilan keputusan dari uji autokorelasi Durbin-Watson yaitu model regresi terdapat autokorelasi jika $\mathrm{D}<\mathrm{DL}$ atau $\mathrm{D}>4-\mathrm{DL}$, namun jika hasilnya $\mathrm{DU}<\mathrm{D}<4 \mathrm{DU}$ maka artinya tidak terdapat autokorelasi. Nilai DL dan DU diambil melalui tabel Durbin-Watson dengan acuan K-2 dan n / observasi sebesar 56, berikut hasil uji Autokorelasi

Tabel 9. Durbin Watson

\begin{tabular}{llll}
\hline \hline & \multicolumn{2}{l}{ Weighted Statistics } & \\
\hline \hline R-squared & 0.032591 & Mean dependent var & 0.124280 \\
Adjusted R-squared & 0.012644 & S.D. dependent var & 0.097978 \\
S.E. of regression & 0.097357 & Sum squared resid & 0.919399 \\
F-statistic & 3.200489 & Durbin-Watson stat & 1.777738 \\
Prob(F-statistic) & 0.043918 & & \\
\hline \hline
\end{tabular}

Tabel 10. Perhitungan Durbin Watson

\begin{tabular}{|c|c|c|c|c|c|}
\hline $\mathrm{N}$ & $\mathrm{D}$ & $\mathrm{DL}$ & $\mathrm{DU}$ & $4-\mathrm{DL}$ & $4-\mathrm{DU}$ \\
\hline 100 & 1,777738 & 1,6337 & 1,7152 & 2,3663 & 2,2848 \\
\hline
\end{tabular}

Setelah dilakukan analisis data, ditemukan bahwa nilai Durbin-Watson1,777738 tidak terjadi autokorelasi, hal ini di tunjukan dengan nilai DU yang lebih kecil dari nilai D yaitu 1,7152 dan nilai 4DU yang lebih besar dari nilai D yaitu sebesar 2,2848. Sehingga dapat diputuskan bahwa semua model regresi terlepas dari problem autokorelasi. Sehingga dapat diputuskan bahwa semua model regresi terlepas dari problem autokorelasi.

\section{Uji Hipotesis}

\section{Koefisien Determinasi}

Koefisien determinasi di gunakan untuk mengukur sampai sejauh mana presentase kemampuan variabel independen mempengaruhi variabel dependen secara simultan. 
Tabel 11. Koefisien Determinasi

\begin{tabular}{ll}
\hline \hline \multicolumn{2}{c}{ Weighted Statistics } \\
\hline \hline R-squared & 0.032591
\end{tabular}

Pada tabel di atas menunjukan banwa nası pengujıan koerısıen determinasi Adjust R Square sebesar 3,2591\%. Yang artinya variabel independen dalam penelitian ini (Umur Perusahaan dan Sales Growth) secara simultan mempengaruhi variabel Tax Avoidance sebesar 3,2591\%.

\section{Hasil Uji Statistik F}

Uji statistik F digunakan untuk mengetahui apakah ada atau tidaknya pengaruh semua variabel independen (simultan) yang dimasukan dalam model regresi berganda secara bersama sama terhadap variabel dependen. Uji dilakukan pada tingkat signifikansi (Sig.) 0,05. Jika nilai probability signifikansi (Sig.) F-statictic lebih kecil dari 0,5 maka Hipotesis diterima yang artinya bahwa variabel independen secara simultan berpengaruh terhadap variabel dependen

Tabel 12. Uji F

\begin{tabular}{ll}
\hline \hline F-Statistic & 3.200489 \\
Prob(F-statistic) & 0.043918 \\
\hline \hline
\end{tabular}

Dari data tabel diatas, dapat dilihat bahwa nilai signifikansi F sebesar 0,043918 lebih kecil dari $\alpha$ 0,05. Maka dapat di ambil kesimpulan bahwa variabel independen (Umur Perusahaan dan Sales Growth) secara simultan berpengaruh terhadap variabel dependen (Tax Avoidance).

\section{Hasil Uji t}

Uji statistik T digunakan untuk mengetahui apakah ada atau tidaknya pengaruh dari masing-masing variabel independen $(\mathrm{x})$ secara parsial atau individu yang di berikan terhadap variabel dependen standar signifikansi di tetapkan $\alpha<0,05$

Tabel 13. Uji t

\begin{tabular}{crrrr}
\hline \hline Variable & Coefficient & Std. Error & t-Statistic & Prob. \\
\hline \hline C & 0.268718 & 0.043076 & 6.238282 & 0.0000 \\
X1 & -0.001120 & 0.001817 & -0.616672 & 0.0489 \\
X2 & -0.012338 & 0.007189 & -1.716215 & 0.0293 \\
\hline \hline
\end{tabular}

\section{Analisis Regresi Linier Berganda}

Analisis regresi linear berganda bertujuan untuk mengetahui pengaruh satu atau lebih variabel independen terhadap variabel dependen. Hasil dari tabel 13 diperoelh persamaan regresi linier:

$\mathrm{Y}=0,268718-0,001120 \mathrm{X} 1-0,012338 \mathrm{X} 2$

\section{Pembahasan}

\section{Pengaruh Umur Perusahaan Terhadap Tax Avoidance}

Berdasarkan tabel 13, hasil uji hipotesis $\mathrm{H} 1$ menunjukan bahwa variabel umur perusahaan berpengaruh terhadap Tax Avoidance. Pada tabel 13 diatas menunjukan nilai hasil koefisien umur perusahaan sebesar - 0,001120 dengan nilai Sig sebesar 0,0489 lebih kecil dari $\alpha$ 0,05. Dengan penjelasan diatas dapat diambil keputusan hipotesis H1 diterima dan dapat disimpulkan bahwa umur perusahaan berpengaruh terhadap Tax Avoidance. Umur Perusahaan berpengaruh terhadap Tax Avoidance sesuai dengan penelitian sebelumnya yang dilakukan oleh Silvia (2017) dan Aji (2019) yang menyatakan bahwa Umur Perusahaan berpengaruh terhadap Tax Avoidance.

Perusahaan memiliki siklus hidup yang semakin lama akan semakin mengalami penurunan. Seiring berjalannya waktu perusahaan akan semakin tidak efisien. Perusahaan yang sudah menua dan 
sudah tidak efisien tentunya akan berupaya agar perusahaannya kembali menjadi efisien. Perusahaan akan mengurangi pengeluaran biaya agar bisa efisien. Salah satu biaya yang dikurangi yaitu biaya pajak. Perusahaan akan berupaya memperkecil biaya pajaknya agar performa perusahaan terlihat baik namun dibalik itu, sebuah perusahaan yang memiliki umur lebih dewasa (memiliki tanggal IPO yang lebih tua) cenderung akan memiliki pengalaman yang baik tentang perilaku tax avoidance dan juga dampak dan cara mengatasi atau meminimalisir dampak dari tax avoidance tersebut, sehingga keputusan melakukan tax avoidance tetap memberikan manfaat untuk perusahaan dengan biaya pajak yang lebih kecil yang harus dibayar oleh perusahaan dan kelebihan dana bisa digunakan untuk transaksi operasional lain.

\section{Pengaruh Sales Growth Terhadap Tax Avoidance}

Berdasarkan tabel 13, hasil uji hipotesis H2 menunjukan bahwa variabel Sales Growth berpengaruh terhadap Tax Avoidance. Pada tabel 13 diatas menunjukan nilai hasil koefisien Sales Growth sebesar - 0,012338 dengan nilai Sig sebesar 0,0293 lebih kecil dari $\alpha$ 0,05. Dengan penjelasan diatas dapat diambil keputusan hipotesis H2 diterima dan dapat disimpulkan bahwa Sales Growth berpengaruh terhadap Tax Avoidance. Sales Growth berpengaruh terhadap Tax Avoidance, sesuai dengan penelitian sebelumnya yang dilakukan oleh (Febby, 2019), (Muhammad, 2020) dan (Afiati, 2019) yang menyatakan bahwa Sales Growth berpengaruh negatif terhadap Tax Avoidance.

Pertumbuhan penjualan akan berdampak kepadasemakin meningkatnya laba yang diperoleh oleh suatu perusahaan. Namun apabila pencapaian sales growth dari tahun ke tahun meningkat secara tidak langsung beban operasional penjualan yang dibebankan juga akan bertambah, dan beban pengenaan pajak yang ditanggung perusahaan akan semakin besar, sehingga perusahaan meningkatkan tindakan tax avoidance agar laba yang dihasilkan perusahaan tidak berkurang karna naiknya beban pengenaan pajak penghasilan.

\section{Pengaruh Umur Perusahaan \& Sales Growth Terhadap Tax Avoidance}

Berdasarkan tabel 12, hasil uji hipotesis H3 menunjukan bahwa variabel Umur Perusahaan \& Sales Growth secara simultan berpengaruh terhadap Tax Avoidance. Pada tabel 12 diatas menunjukan nilai hasil koefisien sig f Umur Perusahaan dan Sales Growth sebesar 0.043918 lebih kecil dari $\alpha$ 0,05. Dengan penjelasan diatas dapat diambil keputusan hipotesis H3 diterima dan dapat disimpulkan bahwa Umur Perusahaan dan Sales Growth secara simultan berpengaruh terhadap Tax Avoidance. Sales Growth berpengaruh terhadap Tax Avoidance, sesuai dengan penelitian sebelumnya yang dilakukan oleh (Silvia, 2017), (Muhammad, 2020) dan (Afiati, 2019) yang menyatakan bahwa umur perusahaan dan Sales Growth berpengaruh terhadap Tax Avoidance.

Perusahaan yang memiliki umur lebih dewasa (memiliki tanggal IPO yang lebih tua) cenderung akan memiliki pengalaman yang baik tentang perilaku tax avoidance dan juga dampak dan cara mengatasi atau meminimalisir dampak dari tax avoidance tersebut terlebih ketika perusahaan mengalami sales growth, sehingga keputusan melakukan tax avoidance tetap memberikan manfaat untuk perusahaan dengan biaya pajak yang lebih kecil yang harus dibayar oleh perusahaan dan kelebihan dana bisa digunakan untuk transaksi operasioanal lain.

\section{SIMPULAN}

Berdasarkan hasil penelitian di atas dapat ditarik kesimpulan:

Dengan tingkat signifikansi 5\%, Umur Perusahaan berpengaruh terhadap Tax Avoidance, Sales Growth berpengaruh terhadap Tax Avoidance. Dan secara simultan Umur Perusahaan dan Sales Growth berpengaruh terhadap Tax Avoidance. 
Penelitian ini hanya menganalisis pengaruh antara construct variabel independen terhadap variabel dependen. Untuk peneliti selanjutnya dapat melakukan penelitian dengan menganalisis pengaruh antara construct variabel independen terhadap construct variabel dependen.

\section{DAFTAR PUSTAKA}

Afiati, N., J., (2019). Pengaruh Return On Assets, Leverage, Sales Growth, Dan Kepemilikan Institusional Terhadap Tax Avoidance (Studi Pada Perusahaan Lq-45 Yang Terdaftar Di Bursa Efek Indonesia Tahun 2015-2018). Tegal : UniversitasPancasakti.

Almaidah M., Kartika H., T., \&Siti N. (2017), Pengaruh Karakteristik Perusahaan, Sales Growth Dan Csr Terhadap Tax Avoidance. Seminar Nasional IENACO - 2017 ISSN: 2337 - 4349. Hal 732 -742 .

Andalia., (2018). Pengaruh Kompensasi Eksekutif, Sales Growth, Financial Distress, Dan Kompensasi Rugi Fiskal Terhadap Tax Avoidance Dengan Komisaris Independen Sebagai Pemoderasi (Studi Pada Perusahaan Pertambangan Yang Terdaftar Di Bei 2014-2017). Makasar: Universitas Islam Negeri Alauddin Makasar.

Annisa (2019), Pengaruh Kompensasi Rugi Fiskal, Sales Growth, Dan Capital Intensity Terhadap Tax Avoidance Pada Perusahaan Manufaktur Yang Terdaftar Di Bursa Efek Indonesia. Sumatera Utara : Universitas Sumatera Utara

Agustin F., Yulia A., N., A. (2016). Pengaruh Corporate Governance dan Sales Growth Terhadap Tax Avoidance (Studi Empiris Pada Perusahaan Otomotif Yang Terdaftar Di Bursa Efek Indonesia Tahun 2010-2014). ISSN : 1693-4482. STAR - Study \& Accounting Research | Vol XIII No.3 2016. Hal: $48-58$.

Almaidah., M ,\& Kartika. H., T., (2016). Pengaruh Ukuran Perusahaan Dan Sales Growth Terhadap Tax Avoidance. Seminar Nasional dan Call Paper Fakultas Ekonomi UNIBA Surakarta. ISBN : 978979-1230-36-0 Hal. $212-223$.

Cahya S., W., \&Riris., R., S., (2019) Pengaruh Transfer Pricing Dan Sales Growth Terhadap Tax Avoidance Dengan Profitabilitas SebagaiVariabel Moderating. Media Akuntansi Perpajakan ISSN(P): 2355-9993 (E):2527-953X Vol. 4, No. 2, Juli. — Des. 2019 : 01-10. Jakarta : Universitas 17 Agustus 1945 Jakarta

Desy F., A., Riana R D.,, \& Rosa N., F., (2020) Pengaruh Corporate Governance dan Sales Growth terhadap Tax Avoidance di Bursa Efek Indonesia (BEI) 2014-2018. ISSN 2597-8829 (Online), Ekonomis : Journal of Economics and Business, 4(1), Maret 2020, Hal: 210-215.

Febby, I., K., D. (2019). Pengaruh Good Corporate Governance, Risiko Perusahaan, Return On Assets (Roa), Dan Sales Growth Terhadap Tax Avoidance (Studi Kasus Pada Perusahaan Manufaktur Sektor Barang Konsumsi Di Bei Tahun 2014-2017). Jakarta :Universitas Mercu Buana

Febri, S., (2018) Pengaruh Capital Intensity, Inventory Intensity Ratio Dan Financial Distress, Terhadap Tax Avoidance (Studi Pada Perusahaan Manufaktur Sub Sektor Makanan Dan Minuman Yang Terdaftar Di Bursa Efek Indonesia Tahun 2014-2016). Riau :Universitas Islam Negeri Sultan Syarif Kasim.

Lidia W., dan Robby., F. (2017). The Effect of Business Strategy, Leverage, Profitability and Sales Growth on Tax Avoidance.(e) 2441-9724. Indonesian Management and Accounting Research. Volume 16 Number 02 July 2017. Hal $67-80$.

Maria Q., M., \& Muhammad, N., A., (2020). Pengaruh Profitabilitas, Leverage, Ukuran Perusahaan, Dan Sales Growth Terhadap Tax Avoidance. Jurnal Akuntansi Trisakti ISSN : 2339-0832 (Online) Volume. 7 Nomor. 1 Februari 2020 Hal:127-138. 
Mayarisa, O., (2017) Pengaruh Karakter Eksekutif, Komite Audit, Ukuran Perusahaan, Leverage, Pertumbuhan Penjualan, Dan Profitabilitas Terhadap Tax Avoidance. ISSN 1412-775X Jurnal Akuntansi Bisnis, Vol. 15, No. 1, Maret 2017, Hal 23 - 40.

Muhammad., A, \& Susi., D. N (2019). Pengaruh Sales Growth Dan Leverage Terhadap Tax Avoidance Dengan Kepemilikan Institusional Sebagai Variabel Moderasi. SSN (P) : 2615 - 2584 Prosiding Seminar Nasional Pakar ke 2 Tahun 2019. Hal: 2.14.1 - 2.14.10

Novita W., T, Kartika H., T, \& Riana., R., D., (2020) Pengaruh Profitabilitas, Size, Leverage, Komite Audit, Komisaris Independen dan Umur Perusahaan terhadap Tax Avoidance. ISSN 2549-4236 Jurnal Ilmiah Universitas Batanghari Jambi, 20(1), Februari 2020, Hal:113-120.

R, S., T, Aji (2019). Pengaruh Kompensasi Eksekutif, Komite Audit, Financial Distress, Ukuran KAP dan Umur Perusahaan Terhadap Tax Avoidance. Semarang : Universitas Katolik Soegija pranata.

Sri W., R., (2019). Pengaruh Intensitas AsetTetap Dan Sales Growth Terhadap Tax Avoidance Dengan Dewan Komisaris Independen Sebagai Variabel Moderating (Studi Kasus Pada Perusahaan Manufaktur Yang Terdaftar Di Bei Periode 2015-2017). Makasar : Universitas Alauddin Makasar. 